\title{
Political Development in Hong Kong: The Failure of Democratization
}

\author{
STEPHAN ORTMANN*
}

\begin{abstract}
Democratization in Hong Kong has come to a dead end following the rejection of an electoral reform proposal by the Legislative Council on June 18, 2015. The measure was voted down because pan-democrats had been deeply disappointed by the fact that the reform proposal by the Chinese government would have only allowed pre-screened candidates and thus denied Hong Kongers a true choice. This followed more than two months of street occupations in which protesters demanded real universal suffrage to no avail. This paper seeks to demonstrate how the "China factor" has inhibited the democratization process in four distinct phases of political development. Since World War II, one of the main reasons for the lack of democratization was opposition by the Chinese government. In the late $1980 \mathrm{~s}$, the prospect of political reforms in China raised hopes for political change in Hong Kong. This was, however, crushed in 1989, which empowered a democracy movement in Hong Kong. Since the transfer of power from Britain to China in 1997, despite protests for democracy, there has been very little progress toward meaningful democratization. Moreover, in recent years, there has even been a slow process from liberal to illiberal authoritarianism which is accompanied by growing conflicts and even violence as political freedoms are being curtailed.
\end{abstract}

Keywords: Hong Kong, China, Democratization, Lack of Autonomy, Liberal Authoritarianism, Illiberal Authoritarianism

\footnotetext{
* Assistant Professor, City University of Hong Kong, Hong Kong; E-mail: sortmann@cityu.edu.hk
}

DOI: 10.16934/isr.17.2.201612.199 


\section{INTRODUCTION}

Hong Kong has experienced a long and protracted democratization process with repeated modest electoral reforms that have allowed for limited contestation without resulting in liberal democracy. Today, slightly more than half of the Legislative Council is elected by direct universal suffrage but the legislators are unable to introduce any meaningful policy changes. Unlike in parliamentarian systems, they are unable to form a government. The executive is still selected by a 1,200member Election Committee that is largely under control of pro-establishment elites. An electoral reform proposal in 2014, which would have opened the way for universal suffrage of the chief executive, was rejected because it would have allowed the committee full control over the nomination process. A democratic candidate would have had no chance of contesting any future elections. The whole episode amply demonstrated that the Chinese government in Beijing is unwilling to grant Hong Kong democratization.

Hong Kong has never progressed beyond partial democratization and instead a liberal authoritarian regime has persisted for a long time (Case 2008). Despite lacking representative institutions, the city-state has maintained freedom of speech and assembly, rule of law, judicial independence, as well as the checks-and-balances that are supposed to constrain government. One example of this are filibusters which have sometimes curtailed the government's ability to push unpopular policies through the Legislative Council. The reason for the unique hybrid regime rests with the territory's particular historical development of British colonialism and the need to increasingly localize politics, as well as the handover of power to China in 1997 which occurred under an arrangement known as "one country, two systems" and was supposed to maintain Hong Kong's uniqueness for at least 50 years. In recent years, however, the freedoms of Hong Kongers have come under increasing threat. For instance, while there has not been any outright repression, freedom of the press has suffered under the change of ownership of media corporations and editors, the denial of licenses, and even attacks on journalists (Fung 2007; Cheung 2016). To explain this decline in freedoms and the failure of democratization, it is necessary to recognize that Hong Kong is not an independent country, which significantly curtails the decision-making of local elites and denies the city-state the right to self-determination.

This paper seeks to place Hong Kong within the broader democratization literature and to demonstrate that the unique nature of the Special Administrative Region, as a part of an illiberal Chinese state, is the main obstacle to a transition to liberal democracy. This power dependence of the semi-autonomous state on the People's Republic of China is a fundamental barrier that cannot be overcome. The reason for this is that China does not allow Hong Kong to exert sufficient autonomy for political self-determination while it clings to its strong belief in the 
importance of centralized governance. The Chinese government believes that this can avoid potential internal conflicts between different regions, something that happened in the past when competing warlords fought against one another. This unfortunately means that comparison with other hybrid authoritarian regimes, as some have attempted, is only of limited value (Fong 2016). In the following, the main arguments regarding why Hong Kong has not democratized will be revisited. This seeks to demonstrate that the "China factor" provides a sufficient explanation why Hong Kong has failed to democratize. Then the process will be studied along four major stages of political development in which the Chinese government has sought to control political elites in Hong Kong. The history of political reforms shows that Chinese influence played an important role even during the colonial period. Political developments in Hong Kong were largely shaped by perceptions of developments on the mainland. When China appeared to progress toward a more inclusive political system, support for Chinese rule increased while greater repression and threats to the residents' freedoms have increased demands for democratization and, most recently, even triggered calls for full autonomy and even independence.

\section{THE DEMOCRATIZATION PROCESS IN HONG KONG}

The lack of democratization in Hong Kong has received significant academic attention over the years, which some scholars have regarded as an exception to modernization theories linking economic development to democratization (Sing 2004; Cheng 2014b). This argument, however, neglects the unique nature of Hong Kong as a former British colony that was transferred to Chinese power and became a Special Administrative Region with a "high degree of autonomy" in 1997 (Basic Law, Article 2). Kuan (1991) thus notes that both Britain and China have restrained the democratization process. During the colonial period, after World War II, the tycoons that controlled the city were vehemently opposed to democratization fearing restrictions on their businesses. Moreover, the Chinese made it clear to the British colonial government that they were opposed to popular democracy, which contributed to the shelving of a plan to democratize Hong Kong after World War II (Tsang 1988; Sing 2004; Ortmann 2015).

While clearly control over Hong Kong by external forces explains the institutional development, scholars have argued that in addition there was little societal pressure for democratization from within the territory. In fact, the administrative state had depoliticized the population and people had become apathetic. This argument was prominent in the 1970s and 1980s during Hong Kong's dramatic economic transformation. However, even today some argue that the unwillingness to participate in politics explains why more people do not join in the democracy movement. Scholars like Lau $(1978 ; 1982)$ blamed this on the prevalent Chinese 
culture and what he termed as "utilitarian familism," a combination of familycentered materialism with utilitarianism that was prevalent at the time even it was in decline. There was also a so-called "refugee mentality" as most recent immigrants had fled the mainland and were now worried about risking their improved living standards (Ma 2007a). A similar argument was made about the middle class in the 1980s and 1990s, many of which had migrated from the mainland with the hope for a better life in the British colony. Due to the moderate nature of the middle class, there was an unwillingness to fight for democracy (So and Kwitko 1990).

With the rise of protests and growing demands for democratization, the societal argument was significantly weakened. However, the belief in the efficacy of societal protest continued. Sing (2004) suggested that the ability to threaten the interests of the Chinese government as well as the capacity to gain support for democratic concessions was crucial for the speed of the democratization process. If only the democracy movement could convince the authorities in Beijing that the local political reform process would not threaten the hegemony of the regime, it could succeed in negotiating for a democratic transition. Moreover, Zhang (2010) argues that Beijing and Hong Kong's democrats could have reached an agreement about the path toward democratization. These arguments are based on the assumption of a balance of power between democrats and the Chinese government. Although it is true that changes to the Basic Law need to be approved by twothirds of the Legislative Councilors and that democrats have been able to maintain their veto-power, it assumes that Beijing has the same interest in electoral reforms as democrats. The failed electoral reform process in 2014-2015, however, demonstrated that this is not the case, as will be discussed later.

In addition to the ineffectiveness to negotiate with Beijing, scholars also pointed to the inability to find consensus between different groups in Hong Kong. For instance, So (2000) argued that the lack of democratization was in part due to the opposition by business people to democracy which led to their "unholy alliance" with Beijing. Overall, the actor-oriented approach sought to analyze the lack of democratic progress as an interaction between pro and anti-democratic groups inside the city. There are indeed significant problems such as weak political parties, lack of connection between civil and political society, and few issues that could unite the fragmented population. The growing divisions within the pan-democratic camp were also viewed with great concern because they suggested that the ability to pressure the authorities to agree to political reforms was diminishing.

The problem with these arguments is the miscalculation about the power distribution between social forces in Hong Kong and the Chinese government. In reality, Beijing is in a superior position and does not need to negotiate. The argument that democrats could possibly negotiate democratic reforms is based on the 
assumption that Chinese interests could be threatened inside the city because China considers Hong Kong indispensable, which is unfortunately misguided. The political development, which produced limited democratic reforms, clearly demonstrates that it is a top-down process and that societal pressures have not significantly contributed to its progress. Instead, unfortunately the opposite has happened as protests have made the Chinese government more reluctant toward democratic reforms because of a fear that Hong Kong could become a subversive base and threaten the power of the one-party state. For this reason, the central government seeks to maintain full control over the political process. Political participation at the grassroots cannot be meaningfully involved in the policymaking process because it would reduce the power of the central government (Preston 2016). Steps toward democratization thus were never meant to move the city-state toward democracy but rather to co-opt powerful elites and reduce pressures for political participation from below.

In order to demonstrate how the Chinese government has shaped the political reform process either directly or indirectly, it is helpful to draw on Ma Ngok's conceptionalization of key stages in the political development process (Ma 2011). However, this model has to be significantly adapted to incorporate the many developments that have happened since to understand the partial regression of democratic development as well as the growing threat of additional de-democratization, or the slide into illiberal authoritarianism. Also, to complete the picture, one needs to account for the time before the first stage which has not only created the basis for the stunted democratization process but also bears far-reaching consequences for today's political development.

\section{THE FIRST STAGE1982-1989: DEMOCRATIC OPTIMISM}

Although the political reform process started in earnest in the 1980s, Hong Kong's democratic development can be traced to the late 1960s and 1970s which saw early experiments with local elections as well as increasing activism by pressure groups that revealed a growing desire of a small but increasing number of professionals to participate in politics. After World War II, the Chinese government made it clear that it was opposed to the development of democracy. As Hong Kong's tycoons were also worried, the colonial government was left with the attempt to administratively incorporate the growing demands for participation into the decision-making process, which has been called the "administrative absorption of politics" (King 1975). This was reflected in increasingly responsive politics in which the governor, especially Sir Murray MacLehose (1971-1982), focused on various popular policies such as making Chinese an official language in 1974, introducing an effective anti-corruption bureaucracy with the Independent Commission Against Corruption (ICAC) in 1974, advancing the public housing pro- 
gram (he announced a ten-year housing policy in 1972), establishing nine-year free compulsory public education (in 1978), strengthening affordable health care and other programs. At the same time, the rapid economic growth produced many opportunities for Hong Kong people.

While the British government wanted to shed its remaining colonies, Hong Kong could not follow the path of other colonies entailing democratization and eventual independence due to strong objections from China, which saw the citystate as an inherent part of its territory (Pepper 2000). It was not surprising that the Chinese had been one of the strongest opponents of meaningful democratic reform in the post-World War II era. However, for most residents in the city, the Chinese Communist regime was viewed with disdain and the political turmoil on the mainland created a generation of refugees who were grateful for the many benefits that living in Hong Kong brought them. The violent disturbances of 1967, influenced by the Mao Zedong's Cultural Revolution, had united most Hong Kongers behind the colonial government (Cheung 2009).

The democratization process started in earnest in the 1980s. 1982 marked the beginning of elected District Boards with universal suffrage electing 132 out of 490 members of 18 newly established boards. This change was supposed to incorporate rising demands for popular participation by strengthening the role of the public in the consultation process without affecting the political system as a whole (Hook 1983). A green and white paper on electoral reform followed in 1984 proposing the introduction of direct elections for some members of the Legislative Council, but the proposal to have the first direct elections in 1988 was rejected (Butenhoff 1999) and instead postponed until 1991. The Basic Law drafting committee was formed in 1985 and represents for Ma Ngok (2011) the beginning of the first stage of the democratization process. This period was marked by heightened political participation as many groups sought to influence the negotiations between China and Britain (Lo 1988). This increased awareness was in part driven by the fact that most people did not look forward to reunification with China and a 1984 survey showed that 37 percent of the population were even in favor of independence while only 26 percent accepted the return to China (Cheng 1984).

In response to the decision to return Hong Kong to China, many Hong Kongers became concerned with the need to guarantee as much autonomy as possible and some argued for democratic elections to achieve this goal. Lo (1988), for example, suggested that "Hong Kong will probably become China's semi-colony if the Hong Kong people do not remain critical of both local government and Chinese policy" (628). Only two democrats, Martin Lee and Szeto Wah, had been invited to participate in the process of writing the future legal framework. The Chinese government was, however, not inclined to grant Hong Kong any kind of liberal democracy and some in the British colonial government even accepted this. For instance, secretary for district administration, David Akers-Jones, said in 1984 
that the political system in Hong Kong must be compatible with China's political structure and fit to the notion of "one-country, two systems" rather than to strengthen the democratic processes (Lim 1984a). Simultaneously, the Chinese government could rely on business interests, which were also opposed to further democratization fearing the introduction of social programs and redistribution. It is thus not surprising that the result of the deliberations on the Basic Law was a heavily pro-business oriented document, which contributed to the massive social discontent that seriously impaired the legitimacy of the post-handover regime.

\section{THE SECOND STAGE1989-2003: THE END OF COLONIALISM AND DEMORATIC UNCERTAINTY}

Today's political situation is deeply rooted in the fatal outcome of the Tiananmen student protests that cost the lives of many Chinese students and bystanders as troops moved into Beijing on June 4, 1989, to remove the activists from the square. Hong Kongers were watching the situation from afar on television and were shocked with disbelief and anger. Many had thought that Deng Xiaoping and his government were reformers who would eventually enable China to become a more democratic regime. As the majority of the population in Hong Kong were refugees from Communism during Mao Zedong's darkest hour, the return of violence was particularly disturbing to them. Moreover, the harsh crackdown demonstrated that the Chinese government was deeply opposed to participatory politics and was willing to use any methods to resist political change. As such, the violence raised concerns about the future of Hong Kong, which would return to Chinese control in 1997. Would the people be able to trust the Chinese government? This crisis created a sense that democratization would be needed to safeguard Hong Kong's future. For So $(1997,51)$, the incident enabled "the service professionals to effectively contest the restricted democratic model of the Basic Law." The strong support for the democracy movement in China, however, also motivated the Chinese government to add an additional provision regarding subversion to the Basic Law known as Article 23 (Chan 1997). As So (1997) argued: "Beijing adopted a much hardened policy toward Hong Kong's democratic movement than before the Tiananmen Incident" (55).

While some Hong Kongers saw the need to plan for emigration to other countries, others responded by strengthening the burgeoning democracy movement. The Legislative Council elections of 1991 constituted a significant step forward in the direction of democratization and provided an opportunity for resistance. It had for the first time directly elected legislators which came from geographical constituencies, although they numbered only 18 in comparison to 21 indirectly elected legislators which were selected through functional constituencies and another 21 unelected members, 3 ex-officio and 18 appointed ones (Scott 1991). The oppor- 
tunity for elections provided the basis for the formation of the pan-democratic camp that dominated politics prior to the handover and remained an important force in the years afterwards, despite electoral reforms meant to weaken them. In 1990, the United Democrats of Hong Kong (UDHK) was formed and after four years, it merged in 1994 with Meeting Point, which had been a prominent pressure group in the 1970s. Following the merger, the newly formed Democratic Party became the most popular force in the city. The party boasted around 500 democracy supporters as its members at the time. The goal of the party was to unite all the democracy forces together within one party. A long-time supporter, Martin Lee, became its chairman. While advocating for accountable government, it presented itself as a mainstream party with a moderate social reform platform (Lau and Kuan 2000).

With the arrival of Chris Patten as the last governor in 1992, there was shortlived progress toward democracy with electoral reforms in 1994 which broadened the rights of political participation in elections. Unsurprisingly, this was met with strong opposition from the Chinese government, which saw this as an attempt to subvert the Communist regime and thus reversed most of the reforms in 1997 when the Legislative Council was replaced with a provisional legislature (So 1997). While only a few democrats had served in the interim institution, they returned with the elections in 1998 with a desire to have a greater influence in the decision-making process (Scott 2000).

In response to the formation of democratic parties, the pro-Beijing side also established its own party in 1992 called the Democratic Alliance for the Betterment of Hong Kong (DAB). In addition, the Liberal Party was established in 1993 to represent the pro-business camp. Both of these parties continue to be part of the pro-Beijing spectrum of parties today (Zheng and Tok 2007). The development of these parties and the inability to form a united front demonstrated that, unlike in the mainland, Hong Kong would not become a one-party regime. Following the handover, the fragmentation of the pan-democratic opposition parties, however, made the pro-Beijing groups appear relatively united. The introduction of a unique form of proportional representation combined with political lists in multi-seat, single-vote constituencies did not lead to stronger parties (Ma 2007b) but instead contributed to the emergence of many smaller and more radical parties (Cheng 2014a).

The support of the pan-democratic camp for the democracy movement in China created a hostile climate in which no negotiation could occur between the two different camps. The democrats were described as traitors to the Chinese nation and thus sidelined from major political decisions. The only two democrats on the Basic Law drafting committee, Martin Lee and Szeto Wah, were removed in 1989 following their criticism of the Chinese government's decision to violently end the peaceful protests. Consequently, the mini-constitution passed without 
significant input from the pan-democratic camp, which deprived it of significant legitimacy. Of course, it was also not put to a referendum. The document granted Beijing significant influence over post-handover politics that could be of use in case of political conflicts in Hong Kong. This happened for the first time in June 1999, just two years after the handover, when the National People's Congress Standing Committee (NPCSC) intervened to require Chinese government permission for the right of abode of children of Hong Kong residents who were born in mainland China. Most Hong Kongers were, however, not opposed to the decision because there was widespread concern about the potential impact of 1.67 million additional residents (Holliday, Ma and Yep 2004).

\section{THE THIRD STAGE2003-2012: PROTESTS AND INCREMENTAL REFORMS}

In the first few years after the handover, there was little pressure for democratization and most people were content with the extent of political autonomy. This, however, changed in 2003 when the Hong Kong government, probably compelled by Beijing, decided to enact legislation that sought to reduce the possibility that a liberal Hong Kong could come a subversive base to the Communist regime (Ma 2005). Perhaps believing the society was passive, the government proposed vague legislation to fulfill the controversial article 23 of the Basic Law requiring the local government to "enact laws on its own to prohibit any act of treason, secession, sedition, subversion against the Central People's Government, or theft of state secrets, to prohibit foreign political organizations or bodies from conducting political activities in the Region, and to prohibit political organizations or bodies of the Region from establishing ties with foreign political organizations or bodies." This finally proved to be an opportunity for democracy activists to mobilize the society against the government. This resulted in a massive march of about 500,000 people on July 1, 2003, that rivaled the march in support of the Chinese democracy movement in 1989. Following the protest, the government was forced to shelve the legislation and the key supporters of the bill secretary for security Regina Yip and financial secretary Antony Leung resigned to regain public confidence for the government (Petersen 2005).

The mobilization of society revealed, and gave voice to, a host of other concerns against the government. The July $1^{\text {st }}$ protests have since played an important part in Hong Kong politics as even the estimated number of protesters has become a highly contested issue because it is often viewed as a gauge of government legitimacy (Lo 2010). In 2004, thousands of protesters again went to the streets, and even though there were fewer people than the year before, the protest still had a significant impact on politics. Most observers believe Beijing eventually decided it could no longer support Tung Chee-Hwa, Hong Kong's first 
chief executive, who resigned in March 2005 officially for "health reasons" despite showing no evidence of illness (Tai 2005). The growing public activism was viewed with great concern by the Chinese government. The rate of participation in July $1^{\text {st }}$ protests, however, declined over the years and suggested greater support for the government. Naturally, without a major issue to mobilize the people, it became harder to gain mass support (Lee and Chan 2010).

With the rise of a former bureaucrat, Donald Tsang, to the position of chief executive, there was a short period of increased public approval for the Hong Kong government (Ku 2009). He had sought to develop a new leadership style combining effective governance with the support of the public. Approval for the Chinese government also grew in this period until around 2008 when the Olympic Games in Beijing were viewed with great interest in Hong Kong. The Closer Economic Partnership Arrangement (CEPA), signed on June 29, 2003, and less restrictions on travel provided an economic boost to the moribund economy (Sing 2006).

Simultaneously, however, the Chinese government maintained its strong opposition to representative democracy and clarified that any political reforms would only occur on its terms. According to Ma (2011), Beijing "stressed that it held final say over matters of constitutional reform, and that future popular elections would never be allowed to put 'unpatriotic' leaders in charge of Hong Kong" (57). This basically referred to the pan-democratic camp which was regarded as under the control of foreign forces. Unsurprisingly, in 2004 the National People's Congress Standing Committee ruled out direct elections for the chief executive and legislative council claiming that Hong Kong was not yet ready. The democratization of Hong Kong had experienced its first major setback. Despite greater support for Beijing until 2008, pan-democrats could maintain their veto power in the Legislative Council elections of that year when they received 60 percent of the vote share despite the prediction that voters might be more willing to vote for proBeijing parties (Sing 2009).

\section{THE FOURTH STAGE OF 2012 TO PRESENT: THE UMBRELLA GENERATION AND THE DEMOCRATIC SETBACK}

The rise to power of Xi Jinping in November 2012 initiated a phase of greater power centralization in mainland China, which also affected the extent of Hong Kong's autonomy. This occurred at a time when support for the Chinese government had again declined because few Hong Kongers had profited from the economic benefits and the inflow of tourists. Parallel traders and migrants strained the local infrastructure, and increased costs of living and housing costs impacted the population, as did cultural conflicts. Fears of a so-called "mainlandization," which threatened to erode Hong Kong's unique society, heightened (Yew and 
Kwong 2014). For instance, mothers from the mainland flooded Hong Kong's hospitals and reduced the available space for beds. Moreover, living costs were increasing at a rapid rate and housing prices made life difficult. A new localist movement arose that not only wanted to protect the local heritage but also demanded preferential treatment for locals over mainlanders. In 2012, people crowd-funded an advertisement in the popular Apple Daily that described these mainlanders as "locusts" that were taking away important resources from locals (Sautman and Yan 2015). One year earlier, Chin Wan (2011), a prolific author, had penned an extremely popular book titled Hong Kong as a City-State which called for increasing the city's autonomy from the mainland. At the same time, there was a rise of anti-mainland protests across the city.

The most recent development saw a massive confrontation between the democratic supporters and an increasingly hardline Chinese government, which categorically rejects participatory democracy and other aspects of constitutional government both on the mainland and in Hong Kong. From December 2013 to May 2014, the government conducted public consultations on the issue of universal suffrage for the chief executive, which had been promised before the handover. Despite receiving thousands of proposals from various individuals, political parties, interest groups and advocacy organizations, the National People's Congress Standing Committee issued a proposal that narrowed down the potential choice of nominees to those who received more than half of the votes of the Nominating Committee whose 1,200 members were dominantly pro-establishment members (Ng 2016). In 2007, Lingnan professor Baohui Zhang had suggested that "a negotiated settlement on Beijing's plan for direct election of the chief executive in 2017 should be attainable, unless Beijing intends to raise the nomination threshold. So far, there is no evidence to indicate that this is the case" (457). Obviously, precisely this had happened in 2014 indicating that negotiations were not a realistic strategy for any meaningful political reform.

Before the consultation had started, activists had formed a group called Occupy Central with Love and Peace (OCLP) in March 2013 which proclaimed to fight for universal suffrage through various means including dialogue, deliberation, civil referendum and civil disobedience. Only in the last instance would there be an occupation of the Central District to force the Chinese and Hong Kong governments to accept the demands for democracy. From June 20 to 29, 2014, OCLP organized an unofficial civil referendum to gauge popular support for genuine democracy. The voters could choose between three different proposals which all included the ability for public nomination, which was at odds with both the Chinese and Hong Kong governments. Nearly 800,000 people participated in the process (Chan 2015). On July $1^{\text {st }}$, after the annual protest drew the largest crowd since 2003, a number of students tested the government by occupying one road in Central Hong Kong and stayed overnight, during which time the police 
arrested 511 people (Cai 2016).

During the civil referendum, on June 10, 2014, the Chinese government released a controversial White Paper on "One Country, Two Systems" which asserted "comprehensive jurisdiction" over the territory and clearly circumscribed the extent of autonomy. It reinforced the assertion that the central government had not decentralized power to Hong Kong. The administrators in the region must "love the country," which suggested that they must act in accordance with central government orders. Even the judiciary was declared as part of the administration raising fears about its independence. This was not unwarranted because Chinese officials and their supporters in Hong Kong have frequently declared that the city did not practice separation of powers because the executive has more power (e.g. Lau 2014; Yeung 2016). Angered, the number of participants in the unofficial referendum increased significantly.

On August 31, 2014, the NPCSC released the electoral reform proposal, which suggested that two to three candidates would be selected by a majority of the current 1,200-member Nominating Committee. It also declared that no other electoral reforms would take place for the Legislative Council, as indicated in the past. Not unsurprisingly, it was immediately met with great opposition. University students announced a week-long class boycott from September 22 to 26 and secondary school students would join on the last day. During this week, professors organized a series of talks about the future of Hong Kong, democracy and other topics near the government headquarters in Admiralty. On the last day in the evening, students under the leadership of Joshua Wong suddenly decided to retake Civic Square, a small space in front of the Legislative Council that had been fenced off two months earlier, leading to the arrest of the student activist ( $\mathrm{Ng} 2016)$.

In the aftermath, the students organized more participants to join in the demonstration. During the next day, the police declared the protest to be illegal and tried to stop protesters from attending but they failed. On September 28 at 1:40 AM, Benny Tai, the main organizer of OCLP declared the official start of the occupation, which had originally been planned for October 1, the Chinese national holiday, to reduce the potential disruptions and increase the number of participants. During that Sunday, the police then tried to forcefully clear the demonstrators by using teargas. The actions were captured on television, as many international media had been following the events. Instead of dispersing the crowds, the unexpected use of such a harsh method led to the participation of many more people who now also protested against police violence (Yuen 2015).

In the face of massive public support, the government failed to clear the roads as occupations spread to other parts of the city including Mong Kok and Causeway Bay. Barricades were put up and road traffic came to a standstill. No one expected the occupation to continue for a long period of time and hardly anyone imagined that it would take 69 days until the last site was cleared $(\mathrm{Ng}$ 
2016). Instead of removing the protesters, the government changed its strategy to gradually delegitimize the movement (Cai 2016). This was not difficult as continued occupation impacted the residents near the sites directly or indirectly. Buses had to be redirected or canceled. Taxis had to take a longer road and many switched to Hong Kong's highly efficient metro system. Some businesses near the sites could not operate effectively during the period. Of course, some also profited from the disturbance including fast food restaurants near Admiralty. Moreover, the air quality in the occupied areas had improved dramatically (Karacs 2014).

The Chinese government demonstrated that it would not compromise with the movement and make any changes to its previous decision. There was one instance when a televised debate was supposed to bring a political solution to the crisis but it never came. The Hong Kong government was unable to grant any concessions because it was impossible to reverse the previous decision by the Chinese government (Staff Reporters 2014). Obviously, there was no interest in negotiating with protesters and finding a mutually acceptable solution. While the local government lost in legitimacy as it failed to remove the protests, the protesters were eventually removed at a time when support for the occupation had declined and with the aid of court orders which demonstrated some support for the legal system (Cai 2016). The reform proposal was eventually rejected by the Legislative Council after pro-Beijing members surprisingly walked out (Tiezzi 2015). Originally, pan-democrats could veto the proposal if they remained united because it required a two-thirds majority. The fact that neither Beijing nor the local government could win over some of the moderates in the democracy camp demonstrated the unwillingness to find a political solution that differed even slightly from the original proposal, thus signifying an unwillingness to grant anything resembling democracy.

The failure to find a compromise on political reform had serious consequences for the political development in Hong Kong. In particular, it strengthened those who argued that Hong Kong's autonomy needs to be defended more vigorously. A growing number of radical groups began to speak more openly for the need to create an independent city-state. In January 2015, Chief Executive Leung Chunying publicly criticized a recent student publication called Hong Kong Nationalism (Undergrad 2014) published by the student union of the University of Hong Kong. He said that the book "advocates that Hong Kong should find a way to selfreliance and self-determination" and then suggested that politicians "with close ties to the leaders of the student movement to advise them against putting forward such fallacies" (Leung 2015, 3-4). This public scolding, however, made the book into a bestseller which quickly sold out and had to be reprinted (Cheung and So 2015). The traditionally pro-Beijing newspaper Sing Pao has thus sarcastically called him the "father of Hong Kong's pro-independence movement" (Lam 2016).

The newly empowered movement proved to be more than a short-lived 
phenomenon. In fact, discussion about independence drew growing public attention. Already in the July $1^{\text {st }}$ protest in 2014 , the former colonial flag was prominently displayed by protesters demanding either full autonomy or even independence (Yeung 2014). In June 2015, the police arrested ten activists of the "National Independent Party" who had planned to detonate bombs (Lo 2015), although serious doubts were raised about the authenticity of the organization (Chen, Lai and Mok 2015). Localist activists became involved in the most violent protest since 1997 which occurred on Lunar New Year in 2016 in Mong Kok and resulted in more than 124 people being injured and 74 arrested (Kwong 2016). Dubbed the Fishball Revolution, activists sought to defend illegal hawkers from engaging in a local tradition which had been tolerated by the police in the past (Lian 2016). After the government banned six pro-independence candidates from contesting in the 2016 Legislative Council election, a large protest was organized by the Hong Kong National Party which was attended by at least 2,500 people, demonstrating a significant increase in support of independence. The activists proudly held up banners proclaiming "Hong Kong independence" (Fitzpatrick 2016). In July 2016, a survey had shown that 17.4 percent of Hong Kong's population supported independence by 2047 when the "one country, two system" principle is set to expire, with support overwhelmingly among young people (Baldwin and Shi 2016). Another survey in August 2016 showed that 61 percent of Hong Kong University students were in favor of it (Cheng 2016).

Despite increasing warnings by Beijing and numerous manipulations in the electoral process (Fong 2016), the Legislative Council election of 2016 resulted in the victory of six localists, some of whom were advocating "self-determination," including two radicals from Youngspiration, Yau Wai-ching as well as Sixtus "Baggio" Leung Chung-hang (Chan 2016). The two made headlines for changing the oath at the swearing-in ceremony and bringing "Hong Kong is not China" flags which Chinese nationalists saw as an insult to the Chinese nation. The battle for the future of democracy had thus moved from an attempt to convince the Chinese government to outright rebellion against it. Perhaps unsurprisingly, the Chinese government intervened and provided a detailed interpretation of the Basic Law, which made it clear that the two elected legislators would be barred from taking office. The High Court eventually agreed with the NPCSC decision (Ellie $\mathrm{Ng}$ 2016). This however did not end the saga and instead turned the issue into a tool for political battles that threatened other legislators who had already successfully taken their oaths. A total of 15 pro-democratic lawmakers have since come under judicial review (Lee and Lau 2016), consequently threatening the very basis of Hong Kong's already limited electoral system.

With the prospects for representative democracy ruled out by the Chinese government, the future of Hong Kong has become more uncertain than ever. The long-cherished political stability of the former British colony hangs in the balance 
as the end of the 50-year period of "one country, two systems" is coming closer. It seems likely that the next years will bring continued political conflict which will erode the city's constitutional regime with potentially disastrous economic consequences. Chief Executive Leung Chun-ying has already announced that the controversial security legislation for Article 23 of the Basic Law, which caused massive protests in 2003, is back on the agenda (Cheung et al. 2016). If this happens, it would mean the end of the current liberal authoritarian regime. Unfortunately, Hong Kongers who support liberal values and democracy are unable to do anything against the eroding autonomy that is entirely dependent on the good will of the Chinese government. As reported in 1984 when the Joint Declaration between China and Great Britain was signed, the residents "will not have diplomatic recourse to anybody if the Chinese renege on the agreement. They will be completely dependent on the sincerity and enlightenment of the Chinese" (Lim 1984b, 8).

\section{CONCLUSION}

This paper demonstrates that Hong Kong's dependence on China has been the decisive factor in restricting the political reform process toward representative democracy. Although scholars have explored the impact of other factors, they have only played a secondary role in determining its direction. This is due to the fact that there is a substantial power imbalance between the two sides. China's central government has consistently remained in a much stronger position, which the growing democracy movement could not challenge because it remained relatively weak and narrowly contained to the confines of the territory. The existence of the principle of "one country, two systems" has meant that political developments between the two places have remained disjointed and the authoritarian country, which reigns supreme, has successfully averted any reforms which could potentially challenge its power.

Recent events have also shattered the optimism of many scholars, who once believed that it could be possible to establish a democracy in Hong Kong to protect the system's autonomy from possible interventions by mainland authorities. They argued that it could prevent "a qualitative change towards a merger of the Hong Kong and Mainland systems" (Holliday, Ma and Yep 2004, 254) but this was never a realistic expectation. Instead, Hong Kong's autonomy is highly contingent on the Chinese government, which itself is not even legally bound to the Basic Law. In fact, Hong Kong's "rule of law" is nestled within a larger system of "rule by law" which can at any time override local decisions.

While the central government has effectively denied Hong Kong the prospect of representative democracy, this has had serious unintended consequences which increasingly threaten the political stability and economic viability of the city. As the Chinese government has been worried about the possibility that democra- 
tization could lead to demands for independence (Pepper 2000), the reluctance to provide meaningful political reforms has led to the emergence of an independence movement that seeks to cut all ties with the mainland (Kwong 2016). To counter this trend, the Chinese and local authorities have indicated a desire to crack down more harshly on these activists, which inevitably means that the political system will become increasingly illiberal. The recent intervention by the Chinese government has already threatened the rule of law. The aversion to give Hong Kong any meaningful institutionalized influence in the overall power structure of the Chinese state has thus resulted in an increasingly volatile situation whose future trajectory has become more uncertain than ever.

\section{REFERENCES}

Baldwin, Claire and Sharon Shi. 2016. "One in Six Support Hong Kong Independence from China-Poll.” Reuters, July 25, accessed November 21, 2016, http://uk.reuters.com/article/uk-hongkong-china-survey-idUKKCN1050HH

Butenhoff, Linda. 1999. Social Movements and Political Reform in Hong Kong. Westwood and London: Praeger.

Cai Yongshun. 2016. The Occupy Movement in Hong Kong: Sustaining Decentralized Protest. Ogdon: Routledge.

Case, William. 2008. "Hybrid Politics and New Competitiveness: Hong Kong's 2007 Chief Executive Election." East Asia 25(4): 365-388.

Chan, Anita. 2016. "The LegCo Election: What Happened, What it Means for Hong Kong's Future, and Why you Should Care." Coconuts HK, September 6, accessed November 25, 2016, http://hongkong.coconuts.co/2016/09/06/ legco-election-what-happened-what-it-means-and-why-you-should-care

Chan, Kin-man. 2015. “Occupying Hong Kong.” Sur-International Journal on Human Rights 12(21): 1-7.

Chan, Ming K. 1997. "The Politics of Hong Kong's Imperfect Transition: Dimensions of the China Factor." In The Challenge of Hong Kong's Reintegration with China edited by Ming K. Chan, 1-30. Hong Kong: Hong Kong University Press.

Chan, Thomas, Lai Ying-kit and Danny Mok. 2015. "Hong Kong Bomb Plot a Conspiracy to Smear Us, Localists Claim, Ahead of Reform Vote." South China Morning Post, June 16, accessed November 25, 2016, http://www. scmp.com/news/hong-kong/politics/article/1822700/hong-kong-bomb-plot-co nspiracy-smear-us-localists-claim

Cheng, Joseph Y. S. (ed.). 1984. Hong Kong: In Search of a Future. Oxford: Oxford University Press.

Cheng, Joseph Y. S. 2014b. "Democratization in Hong Kong: A Theoretical Exception." In Democracy in Eastern Asia: Issues, Problems and Challenges in 
a Region of Diversity edited by Edmund S. K. Fung and Steven Drakeley: 224-245. London: Routledge.

Cheng, Joseph Yu-shek. 2014a. "The Emergence of Radical Politics in Hong Kong: Causes and Impact." China Review 14(1): 199-232.

Cheng, Kris. 2016. “61\% of HKU Students Would Support Independence in a Referendum, Survey Finds." Hong Kong Free Press, August 10, accessed November 21, 2016, https:/www.hongkongfp.com/2016/08/10/61-hku-stu dents-support-independence-referendum-survey-finds/

Cheung, Charles Chi-wai. 2016. Media Power in Hong Kong: Hyper-Marketized Media and Cultural Resistance. Ogdon: Routledge.

Cheung, Gary Ka-wai. 2009. Hong Kong's Watershed: The 1967 Riots. Hong Kong: Hong Kong University Press.

Cheung, Tony and Peter So. 2015. "CY Leung's Hong Kong Independence Criticism Sparks Controversial Book Sales Rush.” South China Morning Post, January 16, accessed November 19, 2016, http:/www.scmp.com/news/hongkong/article/1680411/cy-leungs-hong-kong-nationalism-comments-spark-sal es-rush

Cheung, Tony, Jeffie Lam, Joyce Ng and Gary Cheung. 2016. "Hong Kong Will Move on Controversial Security Law, CY Leung Says, as Beijing Bars Independence Activists from Legco." South China Morning Post, November 7, accessed November 25, 2016, http://www.scmp.com/news/hong-kong/poli tics/article/2043556/beijing-passes-interpretation-hong-kongs-basic-law-legco

Chin Wan. 2011. Heung Gong Sing Bong Lun (Hong Kong as a City-State). Hong Kong: Enrich Publishing.

Fitzpatrick, Liam. 2016. "Hong Kong Makes History with First Pro-Independence Rally." Time, August 5, accessed November 25, 2016, http://time.com/4440 708/hong-kong-independence-china-localist/

Fong, Brian. 2013. "State-Society Conflicts under Hong Kong's Hybrid Regime." Asian Survey 53(5): 854-882.

Fong, Brian. 2016. "In-Between Liberal Authoritarianism and Electoral Authoritarianism: Hong Kong's Democratization Under Chinese Sovereignty, 19972016." Democratization, ahead-of-print.

Fung, Anthony YH. 2007. "Political Economy of Hong Kong Media: Producing a Hegemonic Voice.” Asian Journal of Communication 17(2): 159-171.

Holliday, Ian, Ma Ngok and Ray Yep. 2004. “After 1997: The Dialectics of Hong Kong Dependence.” Journal of Contemporary Asia 34(2): 254-270.

Hook, Brian. 1983. "The Government of Hong Kong: Change Within Tradition." The China Quarterly 95: 491-511.

Karacs, Sarah. 2014. "Hong Kong's Air Quality Falls After Occupy Clearance Puts Traffic Back on the Roads." South China Morning Post, December 17, accessed November 28, 2016, http://www.scmp.com/news/hong-kong/article/ 
1663503/hello-pollution-toxic-pm25-levels-rise-again-after-hong-kong-clears? page $=$ all

King, Ambrose. 1975. "Administrative Absorption of Politics in Hong Kong: Emphasis on the Grass Roots Level." Asian Survey 15(5): 422-439.

$\mathrm{Ku}$, Agnes Shuk-mei. 2009. "Contradictions in the Development of Citizenship in Hong Kong: Governance without Democracy." Asian Survey 49(3): 505-527.

Kuan Hsin-chi. 1991. "Power Dependence and Democratic Transition: The Case of Hong Kong." The China Quarterly 128: 774-793.

Kwong, Ying-ho. 2016. "State-Society Conflict Radicalization in Hong KongThe Rise of 'Anti-China' Sentiment and Radical Localism." Asian Affairs 47(3): 428-442.

Lam, Jermain TM. 2015. "Political Decay in Hong Kong after the Occupy Central Movement." Asian Affairs: An American Review 42(2): 99-121.

Lam, Oiwan. 2016. "How the Pro-Beijing Sing Pao Newspaper Turned Against CY Leung." Hong Kong Free Press, September 24, accessed November 21, 2016, https://www.hongkongfp.com/2016/09/24/how-the-pro-beijing-sing-paonewspaper-turned-against-cy-leung/

Lam, Wai-man. 2004. Understanding the Political Culture of Hong Kong: The Paradox of Activism and Depoliticization. Armonk: ME Sharpe.

Lau Siu-Kai and Kuan Hsin-Chi. 2000. "Partial Democratization,' Foundation Moment' and Political Parties in Hong Kong." The China Quarterly 163: 705-720.

Lau Siu-kai. 1978. "Utilitarian Familism: The Basis of Political Stability in Hong Kong." Chinese University of Hong Kong, Social Research Centre, Occasional Paper, No. 74.

Lau Siu-kai. 1982. Society and Politics in Hong Kong. Hong Kong: Chinese University Press.

Lau, Stuart. 2014. "Top Justice Officials Back Independence of Hong Kong Courts." South China Morning Post, January 13, accessed November 24, 2016, http:// www.scmp.com/news/hong-kong/article/1404771/top-justice-officials-backindependence-hong-kong-courts

Lee, Eddie and Chris Lau. 2016. "Pro-Beijing Group Member Asks Hong Kong Court to Disqualify 11 Lawmakers over Legco Oaths." South China Morning Post, November 14, accessed November 22, 2016, http://www.scmp.com/ news/hong-kong/law-crime/article/2045801/pro-beijing-group-member-askshong-kong-court-disqualify-11

Lee, Francis L. F. and Joseph M. Chan. 2010. Media, Social Mobilisation and Mass Protests in Post-Colonial Hong Kong: The Power of a Critical Event. London: Routledge.

Lian, Joseph Yizheng. 2016. "Why the 'Fishball Revolution' Must Prompt New Thinking." Hong Kong Economic Journal, February 23, accessed November 
25, 2016, http://www.ejinsight.com/20160223-why-the-fishball-revolution-mu st-prompt-new-thinking/

Lim, Teresa. 1984a. "Colony's Slow Road to Democracy." The Business Times, August 21:8.

Lim, Teresa. 1984b. "Sealing Hongkong's Fate." The Business Times, September 21: 8.

Lo, Clifford. 2015. "10 Activists Held in 'Plot to Detonate Bombs' as Hong Kong Debates Reform Bill.” South China Morning Post, June 15, accessed November 21, 2016, http://www.scmp.com/news/hong-kong/law-crime/article/1822 142/10-activists-held-plot-detonate-bombs-hong-kong-debates

Lo, Shiu-hing. 1988. "Decolonization and Political Development in Hong Kong: Citizen Participation.” Asian Survey 28(6): 613-629.

Lo, Sonny Shiu-hing. 2010. Competing Chinese Political Visions: Hong Kong Vs. Beijing on Democracy. Santa Barbara: Praeger.

Lo, Sonny Shiu-Hing. 2015. Hong Kong's Indigenous Democracy: Origins, Evolution and Contentions. London: Palgrave Macmillan.

Ma Ngok. 2005. "Civil Society in Self-Defense: The Struggle Against National Security Legislation in Hong Kong." Journal of Contemporary China 14(44): 465-482.

Ma Ngok. 2007a. "Democratic Development in Hong Kong: A Decade of Lost Opportunities." In The Hong Kong Special Administrative Region in Its First Decade edited by Joseph Y.S. Cheng: 49-74. Hong Kong: City University of Hong Kong Press.

Ma Ngok. 2007b. Political Development in Hong Kong, State, Political Society, and Civil Society. Hong Kong: Hong Kong University Press.

Ma Ngok. 2011. "Hong Kong's Democrats Divide." Journal of Democracy 22(1): 54-67.

Ng, Ellie. 2016. "Elected Localist Lawmakers Barred from Hong Kong Legislature as Gov't Wins Legal Challenge.” Hong Kong Free Press, November 15, accessed November 21, 2016, https://www.hongkongfp.com/2016/11/15/bre aking-localist-lawmakers-face-ejection-from-hong-kong-legislature-as-govtwins-legal-challenge/

$\mathrm{Ng}$, Jason. 2016. Umbrellas in Bloom: Hong Kong's Occupy Movement Uncovered. Hong Kong: Blacksmith Books.

Ortmann, Stephan. 2010. Politics and Change in Singapore and Hong Kong: Containing Contention. London and New York: Routledge.

Ortmann, Stephan. 2015. "The Umbrella Movement and Hong Kong's Protracted Democratization Process." Asian Affairs 46(1): 32-50.

Pepper, Suzanne. 2000. "Elections, Political Change and Basic Law Government: The Hong Kong System in Search of a Political Form.” The China Quarterly 162: 410-438. 
Petersen, Carole J. 2005. "Hong Kong's Spring of Discontent: The Rise and Fall of the National Security Bill in 2003." In National Security and Fundamental Freedoms: Hong Kong's Article 23 edited by Fu Hualing, Carole J. Petersen and Simon N. M. Young: 13-62. Hong Kong: Hong Kong University Press.

Preston, Peter W. 2016. The Politics of China-Hong Kong Relations: Living with Distant Masters. Cheltenham: Edward Elgar.

Sautman, Barry and Hairong Yan. 2015. "Localists and 'Locusts' in Hong Kong: Creating a Yellow-Red Peril Discourse.” Maryland Series in Contemporary Asian Studies 2.

Scott, Ian. 1991. "Chapter One: An Overview of the Hong Kong Legislative Council Elections of 1991." Asian Journal of Public Administration 13(2): 11-37.

Scott, Ian. 2000. "The Disarticulation of Hong Kong's Post-Handover Political System." The China Journal 43: 29-53.

Sing, Ming. 2004. Hong Kong's Tortuous Democratization: A Comparative Analysis. London: Routledge Curzon.

Sing, Ming. 2006. "The Legitimacy Problem and Democratic Reform in Hong Kong." Journal of Contemporary China 15(48): 517-532.

Sing, Ming. 2009. "Hong Kong's Democrats Hold Their Own." Journal of Democracy 20(1): 98-112.

So, Alvin Y. 1997. "The Tiananmen Incident, Patten's Electoral Reforms, and the Roots of Contested Democracy in Hong Kong." In The Challenge of Hong Kong's Reintegration with China edited by Ming K. Chan: 49-83. Hong Kong: Hong Kong University Press.

So, Alvin Y. 2000. "Hong Kong's Problematic Democratic Transition: Power Dependency or Business Hegemony?" The Journal of Asian Studies 59(2370).

So, Alvin Y. and Ludmilla Kwitko. 1990. "The New Middle Class and the Democratic Movement in Hong Kong." Journal of Contemporary Asia 20(3): 384398.

Staff Reporters. 2014. "Talks Fail to Narrow Gap between Student Leaders and Hong Kong Government." South China Morning Post, October 21, accessed November 25, 2016, http:/www.scmp.com/news/hong-kong/article/1621694/ talks-fail-narrow-gap-between-student-leaders-and-government

Tai, Benny YT. 2005. "Tale of the Unexpected: Tung's Resignation and the Ensuing Constitutional Controversy.” Hong Kong Law Journal 35(1): 7-16.

Tiezzi, Shannon. 2015. "Hong Kong's Legislature Rejects Beijing-Backed Election Plan." The Diplomat, June 18, accessed November 25, 2016, http:// thediplomat.com/2015/06/hong-kongs-legislature-rejects-beijing-backed-elec tion-plan/

Tsang, Steve Yui-sang. 1988. Democracy Shelved: Great Britain, China, and Attempts at Constitutional Reform in Hong Kong, 1945-1952. Oxford: Oxford University Press. 
Undergrad. 2014. Hoeng Gong Man Zuk Leon (Hong Kong Nationalism). Hong Kong: Hong Kong University Students' Union.

Yeung SC. 2014. "Hong Kong Youth Start Entertaining Idea of Independence." Hong Kong Economic Journal, July 2, accessed November 25, 2016, http:// www.ejinsight.com/20140702-youngsters-have-rising-interest-in-hk-indepen dence/

Yeung, Paul. 2016. "HK's Political System Not a 'Separation of Powers," China Daily, October 20, accessed November 24, 2016, http://www.chinadailyasia. com/opinion/2016-10/20/content 15514035.html

Yew Chiew Ping and Kwong Kin-Ming. 2014. "Hong Kong Identity on the Rise." Asian Survey 54(6): 1088-1112.

Yuen, Samson. 2015. "Hong Kong after the Umbrella Movement: An Uncertain Future for 'One Country Two Systems." China Perspectives 2015(1): 49-53. Zhang Baohui. 2010. "Beijing's 2007 Political Reform Plan and Prospects for Hong Kong's Democratization." Democratization 17(3): 442-464.

Zheng Yongnian and Tok Sow Keat. 2007. "Beijing Responds to Hong Kong's Democratization Movement: From Bureaucratic Control to Political Leadership." Asian Affairs: An American Review 33(4): 235-256. 